\title{
PELATIHAN PENGGUNAAN MEDIA PEMBELAJARAN UNTUK MENINGKATKAN PEMAHAMAN DALAM MENENTUKAN VOLUME BANGUN RUANG BAGI SISWA SEKOLAH DASAR
}

\author{
Mahsup $^{1^{*}}$, Islahudin $^{2}$, Yunita Septriana Anwar ${ }^{3}$ \\ ${ }^{1 *}$ Program Studi Pendidikan Matematika Universitas Muhammadiyah Mataram \\ ${ }^{2}$ Program Studi Pendidikan Fisika Universitas Muhammadiyah Mataram \\ ${ }^{3}$ Program Studi Pendidikan Matematika Universitas Muhammadiyah Mataram \\ ${ }^{*}$ Corresponding author \\ E-mail : supyeka@gmail.com
}

Diterima 2 November 2018, Disetujui 7 November 2018

\begin{abstract}
ABSTRAK
Solusi yang ditawarkan dalam kegiatan pengabdian yaitu untuk memudahkan siswa dalam menentukan volume bangun ruang dan dapat meningkatkan pemahaman siswa dalam menentukan volume bangun ruang. Tempat kegiatan pengabdian di SD desa Lemba Sempaga Kecamatan Narmada Kabupaten Lombok Barat. Metode pelaksanaan kegiatan pengabdian terdiri dari persiapan, perencanaan dan pelaksanaan. Hasil kegiatan pengabdian berupa pelatihan sangat bermanfaat untuk meningkatkan pemahaman siswa dalam menggunakan media matematika dalam menentukan volume bangun ruang dan Kegiatan pelatihan dapat membuat siswa antusias dalam belajar dan mendorong siswa untuk lebih aktif serta pemahaman siswa terhadap materi bangun ruang meningkat.
\end{abstract}

Kata Kunci : Media Pembelajaran, Bangun Ruang

\section{ABSTRACT}

The solutions offered in service activities are to facilitate students in determining the volume of building space and can improve students' understanding in determining the volume of building space. The place for service activities in Scholl Elementary Lemba Sempaga Village, Narmada District, West Lombok Regency. The method of implementing service activities consists of preparation, planning and implementation. The results of the service activities in the form of training are very useful to improve students 'understanding in using mathematical media in determining the volume of building space and training activities can make students enthusiastic in learning and encourage students to be more active and students' understanding of building materials increases.

Keywords: Instructional Media, Build Space

\section{ANALISIS SITUASI}

Desa Lemba Sempaga di Kecamatan Narmada Kabupaten Lombok Barat merupakan wilayah yang sangat strategis sebagai tempat pengembangan pembangunan pada masa yang akan datang. Pengembangan tersebut meliputi bidang ekonomi, industri, dan pertanian.Berdasarkan geografisnya, wilayah Lemba Sembaga sebagian besar merupakan dataran rendah yang sangat luas dan subur dengan dikelilingi oleh pegunungan.

Berdasarkan keadaan alamnya yang sangat subur, bidang pertanian merupakan sumber pencaharian terbesar khususnyan tanaman padi dan sayur-sayuran. Hal ini terjadi karena sebanyak $90 \%$ wilayah merupakan daerah persawahan yang sangat cocok ditanami oleh tanaman seperti padi, jagung, sayur maupun tanaman holtikultura lainnya. Dengan adanya keadaan seperti ini, desa Lemba Sempaga merupakan salah satu desa penghasil padi terbesar selain desa lain yang ada diwilayah Lombok.

Dalam bidang pendidikan anak siswa SD kelas $V$ dan VI di desa Lemba Sempaga masih tergolong rendah karena perhatian para orang tua terhadap pendidikan anak-anaknya masih kurang. Hal ini disebabkan karena dari latar belakang pendidikan para orang tua yang rata-rata tamatan SMA dan pekerjaan para orang tua yang mayoritas sebagai petani sehingga perhatian terhadap anak pada siswa SD kelas $\mathrm{V}$ dan $\mathrm{VI}$ masih rendah. Dengan melihat penomena tersebut sangat berpengaruh terhadap pendidikan anak.

Kemampuan siswa SD kelas V dan VI di desa Lemba Sempaga dalam menentukan volume bangun ruang masih tergolong sangat rendah terutama dalam menentukan volume balok, volume kerucut dan volume limas karena bersifat abstrak. Untuk memudahkan anak dalam menentukan volume bangun ruang disajikan dalam bentuk yang 
konkrit maka perlu ada media yang membantu dalam proses tersebut.

Dalam pembelajaran disekolah rumus Matematika sangat menakutkan bagi siswa, terutama rumus Bangun Ruang Sisi Lengkung (BRSL). Sementara, guru kesulitan menjelaskan materi tentang Volum Bangun Ruang Sisi Lengkung (BRSL). Berdasarkan pengalaman saya sebagai dosen pengajar pada mata kuliah workshop matematika, dimana mahasiswa mengalami kesulitan pada saat memebuat media bangun ruang dan menentukan volume bangun ruang, sehingga tim pengabdian kepada masyarakat mencoba melakukan kegiatan sosialisasi penggunaan media matematika bagi siswa SD kelas V dan VI yang ada di desa Lemba Sempaga Kecamatan Narmada Kabupaten Lombok Barat.

\section{Solusi yang Ditawarkan}

Solusi yang ditawarkan setelah mengikuti kegiatan Pelatihan penggunaan media timbangan bilangan sebagai berikut :

a. Penggunaan media matematika dapat memudahkan siswa dalam menentukan volume bangun ruang.

b. Dengan menggunakan media dapat meningkatkan pemahaman siswa dalam menentukan volume bangun ruang.

\section{Target Luaran}

Dari kegiatan pengabdian masyarakat diharapakan dapat memberikan manfaat sebagai berikut :

a. Manfaat Teoritis

Bagi siswa SD Kelas V dan VI dengan menggunakan media matematika dapat memudahkan siswa dalam melakukan perhitungan matematika

b. Manfaat Praktis

Anak SD kelas $\mathrm{V}$ dan $\mathrm{VI}$ dapat menjadikan media matematika sebagai alat yang dapat membantu dalam melakukan proses berhitung matematika

\section{Sasaran Kegiatan}

Sasaran kegiatan adalah anak SD Kelas $V$ dan VI dengan jumlah anak sekitar 20 orang yang berada di desa Lemba Sempaga atau lokasi KKN mahasiswa UM Mataram.

4. Waktu dan Tempat

a. Waktu Kegiatan

Kegiatan dilaksanakan selama 1 hari yang dirangkaikan dengan realisasi Program Mahasiswa KKN.

b. Tempat Kegiatan

Kegiatan dilakukan di posko mahasiswa KKN di desa Lemba Sempaga Kecamatan Narmada Kabupaten Lombok Barat.

\section{METODE PELAKSANAAN}

Metode pelaksanaan kegiatan pengabdian

melalui beberapa tahapan yaitu :

1. Persiapan

Kegiatan persiapan ini dimulai dengan kegiatan observasi untuk mengetahui kondisi di sekolah berkaitan dengan kegiatan pelatihan dan bagiamana sistematika pelatihan yang dilakukan di sekolah. Kegiatan persiapan ini juga dilakukan dengan kegiatan wawancara terhadap pihak sekolah. Berdasarkan hasil observasi dan wawancara tersebut, tim pengabdian melakukan diskusi internal dan mengkaji literatur guna membahas solusi yang dapat digunakan untuk membantu permasalahan yang ada di sekolah tersebut berkenaan dengan kegiatan pelatihan. Selain itu tim pengabdian melakukan diskusi dengan mahasiswa KKN dalam penyusunan jadwal kegiatan yang akan dilakukan selama kegiatan pelatihan.

2. Perencanaan

Dalam kegiatan perencanaan tim pengabdian mempersiapkan alat dan bahan dalam pembutan media bangun ruang dan membagi tugas dengan tim pengabdian.

3. Pelaksanaan

Kegiatan pelaksanaan pengabdian dengan menerapkan langkah-langkah pembuatan media bangun ruang dan pendampingan dalam pembuatannya. Selain itu berdiskusi dengan siswa dalam penerapan volume bangun ruang yang berkaitan dengan permasalahan matematika.

\section{HASIL DAN PEMBAHASAN}

1. Pelaksanaan Kegiatan

Kegiatan sosialisasi mengggunakan media matematika untuk menentukan volume bangun ruang dilaksanakan selama 1 hari didesa Lemba Sempaga Kecamatan Narmada Kabupaten Lombok Barat. Sebelum kegiatan dilaksanakan tim pengabdian kepada masyarakat menyiapkan media berupa balok, Prisma, Tabung, kerucut dan Bola. Tim juga berkomunikasi dengan mahasiswa UM Mataram yang melaksanakan KKN di desa Lemba Sempaga, kami meminta mahasiswa untuk mengumpulkan siswa SD mulai dari kelas $\mathrm{V}$ dan $\mathrm{VI}$ sebanyak 15 orang. Kegiatan pengabdian dilaksanakan diposko mahasiswa KKN Lemba Sempaga dan semua mahasiswa KKN terlibat dalam kegiatan pengabdian kepada masyarakat yang dilaksanakan oleh tim pengabdian.

Sebelum kegiatan pengabdian kami terlebih dahulu menjelaskan materi volume bangun ruang dimana kami menjelaskan Isi (volume) suatu bejana (bangun ruang berongga) adalah banyaknya satuan volume (satuan takaran) yang dapat digunakan untuk mengisi hingga penuh bejana tersebut.

Rumus-rumus volume bangun ruang: prisma, tabung, kerucut, limas dapat diturunkan dari rumus volume balok. Oleh sebab itu rumus volume balok harus lebih dulu ditemukan siswa melalui 
peragaan balok yang diisi kubus satuan. Kemudian tim pengabdian menjelaskan proses menemukan volume balok dan kubus dimana menggunakan alat peraga balok dan kubus transparan yang dilengkapi dengan kubus satuan.

Cara Penggunaan

Tim pengabdian mengajak siswa SD untuk mengukur volume balok dengan cara mengisikan kubus-kubus satuan ke dalam balok transparan satu demi satu sambil membilang: satu, dua, tiga, dan seterusnya sehingga ruangan balok terisi penuh secara merata.Dengan cara yang sama, kita ajak siswa untuk mengukur volume kubus transparan.

Dalam hal ini tim pengabdian memberikan penanaman konsep bahwa volume suatu bangun ruang adalah banyaknya satuan takaran (dalam hal ini satuan takarannya berbentuk kubus satuan) yang dapat digunakan untuk mengisi seluruh bagian dalam bangun ruang itu hingga penuh. Melalui tanya jawab siswa dapat menyimpulkan bahwa banyaknya kubus satuan itulah yang kemudian disebut volume dari balok. Kemudian untuk dapat menemukan rumus volume balok atau disebut juga prisma tegak segiempat,

Saat memulai pelatihan pengabdian kepada masyarakat dilaksanakan, tim pengabdian terlebih dahulu memberikan materi apersepsi, yaitu dengan menunjukkan volum-volum bangun ruang sisi datar dan kemudian diarahkan untuk membuat kesimpulan bahwa volum bangun ruang itu adalah luas alas kali tinggi $(V=L \times T)$.
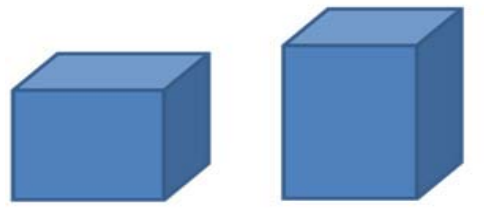

Kegiatan pembelajaran dilanjutkan dengan penunjukkan alat peraga Bangun Ruang (Kubus, Balok, Prisma, Tabung, Kerucut dan Bola). Khusus BRSL (Tabung, Kerucut dan Bola) dengan ukuran tinggi tabung sama dengan tinggi kerucut, tinggi kerucut sama dengan diameter bola dan diameter alas kerucut sama dengan diameter bola.

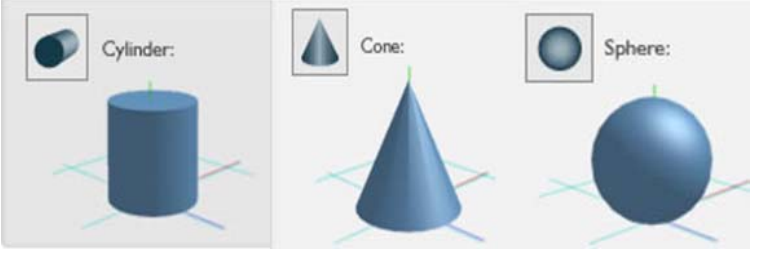

Menyiapkan beras atau pasir sebagai alat praktek untuk membuktikan teori dari volum Tabung, Kerucut dan Bola. Peserta sosialisasi dikelompokkan berdasarkan nama-nama BRSL (kelompok Tabung, kelompok Kerucut dan kelompok Bola).
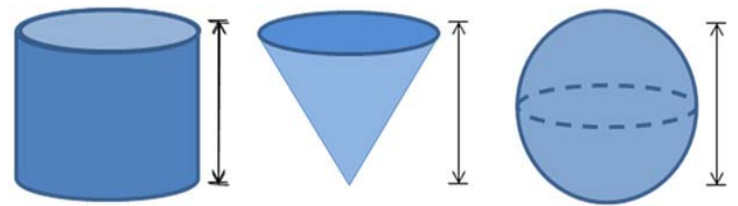

Setelah peserta mempraktikkannya, kemudian menuliskan rumus yang sudah ditemukannya lalu mempresentasikannya di depan, agar apa yang sudah difahami dapat dikembangkan dalam diskusi dengan teman-teman sesama peserta.

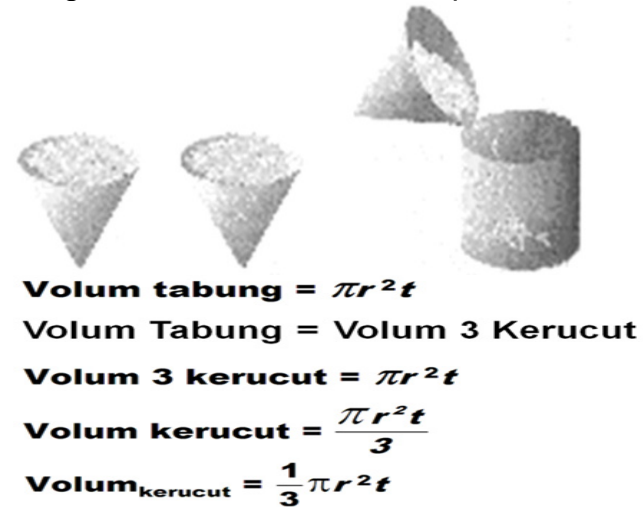

HUBUNGAN VOLUM KERUCUT DENGAN VOLUM BOLA
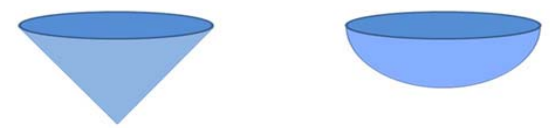

Volum Kerucut $=$ Volum setengah Bola

Volum Setengah Bola $=$ Volum Kerucut

Volum Bola $=$ Volum 2 Kerucut

Volum bola $=2 \times \frac{\pi r^{2} t}{3}$

Volum bola $=2 \times \frac{\pi r^{2} 2 r}{3}$

Volum bola $=\frac{4}{3} \pi r^{3}$

Dengan melakukan praktik langsung, peserta lebih mudah menjelaskan dan mengingat rumus-rumus volum Bangun Ruang Sisi Lengkung (BRSL) dan mengaplikasikannya dalam pembelajaran di kelas. Jika memungkinkan, hal tersebut bisa lebih dimodifikasikan dengan menggunakan teknologi animasi yang lebih menarik lagi.

\section{Kontribusi Mitra}

Kegiatan sosialisasi memberikan kntribusi baik bagi siswa dan sekolah. Adapun kontribusi bagi siswa yaitu:

a. Siswa dapat mengetahui cara menggunakan media matematika dalam menentukan volume bangun ruang

b. Siswa lebih mudah memahami materi bangun ruang terutama menentukan volume bangun ruang menggunakan media matematika 
c. Siswa lebih antusias dan termotivasi dalam belajar khususnya belajar matematika yang berkaitan dengan materi bangun ruang.

\section{Potret Permasalahan Mitra}

Kegiatan sosialisasi menggunakan media matematika dalam menentukan volume bangun ruang bagi siswa SD baru pertama kali dilaksanakan. Ada beberapa masalah yang ditemukan dalam kegiatan sosialisasi yaitu:

a. Ada beberapa siswa kurang antusias karena siswa yang dihadirkan oleh mahasiswa KKN mulai dari kelas III sampai VI padahal materi bangun ruang mulai diajarkan mulai dari kelas $\mathrm{V}$

b. Media yang disediakan oleh tim pengabdian jumlahnya masih terbatas tidak sesuai dengan jumlah siswa mengikuti kegiatan sosialisasi.

c. Kurangnya pemahaman siswa dalam menggunakan media matematika dalam menentukan volume bangun ruang.

\section{SIMPULAN DAN SARAN}

\section{Simpulan}

Kegiatan pengabdian kepada masyarakat berupa pelatihan dalam menentukan volume bangun ruang di desa Lemba Sempaga dapat disimpulkan sebagai berikut:

a. Kegiatan pelatihan sangat bermanfaat untuk meningkatkan pemahaman siswa dalam menggunakan media matematika dalam menentukan volume bangun ruang

b. Kegiatan pelatihan dapat membuat siswa antusias dalam belajar dan mendorong siswa untuk lebih aktif.

\section{Saran}

Dalam melakukan kegiatan pengabdian kepada masyarakat, tim pengabdian harus mengetahui jumlah peserta dan menyediakan media sesuai dengan jumlah peserta yang mengikuti kegiatan pengabdian. Diharapkan para orang tua siswa dan guru disekolah dapat mengenalkan media matematika sejak dini atau mulai dari kelas $1 \mathrm{SD}$.

\section{DAFTAR RUJUKAN}

Bernard, 2017. Media Pembelajaran Matematika. Yogyakarta : depublish

Tim penyusun, 2016. Buku Pedoman Pengabdian Kepada Masyarakat. Mataram : UMMat 